\title{
ЗУЛФИЯ ИЖОДИГА АДАБИЙ ТАЪСИРНИНГ САМАРАЛАРИ
}

\author{
Умурова Гуззал Хотамовна, \\ СамДЧТИ катта ўқзтувчиси, филология фанлари номзоди
}

Калит суизлар: Адабий таъсир, бадиий махуорат, лирик кечинма, методология, адабий мерос, интертекстуаллик.

Зулфия ижодида адабий таъсирнинг роли масаласига ойдинлик киритишга уринар эканмиз, биз ўрни-ўрни билан тахлилнинг хам контекстуал, хам имманент кўринишларидан фойдаланамиз.

Академик Б.Назаров “Адабий таъсир ва типологик яқинликни ўрганишнинг айрим методологик масалаларига доир" мақоласида адабий таъсирга қуйидагича таъриф беради: “Адабий таъсир қўшни, ёндош, замон ва макон масаласида ички хамда турлича манзил ва олисликдаги адабиётлардан уурганиш асосидаги такомиллашув манбаи, жараёни ва хосиласи" [2,6]. Демак, хар қандай миллий адабиёт ўз қобиғи атрофида тўла-тўкис ривожлана олмайди, бунинг учун ташқи адабий таъсир, ўзаро яқинлик зарур бўлади. Ўзбек шеърияти ўтган аср бошларида аруздан бармоқ томон силжиган экан, бу ўзгаришлар хам адабий алоқалар ва унинг таъсирида кечганига шубха йўқ. Айни шу даврда яшаб ижод қилишни бошлаган, шу адабий мухитдан нафас олган Зулфия ижодида адабий таъсир, ижодий ўрганиш, ўзлаштириш жараёни қандай кечди?

Бу саволга шоиранинг шеьриятдаги илк қадамлари хақидаги сўзларидан жавоб топамиз: “30-йилларда Лермонтов, Некрасов, Пушкин, Фет, Тютчев шеърларини биринчи марта рус тилида ўқиб чиқдим ва шоир учун мухими фақат нимани айтишгина эмас, қандай айтиш хам эканлигини англаб етдим... Менинг шеърларимнинг шаклланишида, керакли, ягона сўзни излаб топиш тажрибасида бу ишнинг машаққатини яхши биладиган, чинакам катта шоир Хамид Олимжоннинг хизмати улкан бўлди...” (“Камалак”, 128б.)
Кўринадики, ўзбек мумтоз адабиёти намуналари билан танишиб чиққанидан сўнг, шоирада бошқа халқларнинг адабий меросига қизиқиш, улардаги илғор тажрибалардан ўрганиш эхтиёжи пайдо бўлган. Бу эхтиёж кун сайин кучая борганидан у рус тилини чукурроқ ўрганишга ва улуғ шоирларнинг асарлари билан яқиндан танишишга қарор қилади. Шу ўринда, адабий таъсирнинг ўзига хос кўриниши - бир-бирига кўнгил кўйган икки ижодкор ўртасидаги мулоқот, ижодий ўзлаштириш хақида хам эслаб ўтиш зарурдек: “1937 йилда иккинчи китобим - “Қизлар кўшиғи” босилиб чикди, лекин бу китоб хам шеъриятдаги ақалли ибтидоий камолотнинг, чинакам махоратнинг бўсағаси бўлолмади. Энди ёзмасдан тура олмайдиган бўлиб қолган эдим, шекилли - китоб чиқариш гашти хар нарсадан кучли-да, - лекин нима хақида ёзаримни хали астойдил билмасдим, шунинг учун буни қандай қилиш кераклигини тушуна олмас эдим. Иккинчи китобни ёзаётганимда бир куни Хамид Олимжондан шундай деб сўраганим эсимда: "Нима учун илк ёзган шеьрнинг хеч поёни бўлмайди? Қайси бандда тўхтатмайин, яна давом эттирса бўлаверади-я!"” У кулиб туриб, бундай деган эди: “Чунки хар бир шеърингизда бира тўла хамма гапни айтиб олмоқчи бўласиз, вахоланки, бундай қилиш ярамайди. Кейин, биласизми, шеърни охиридан бошлаб ёзиш керак..." Унинг маслахати нақадар нозик ва аниқлигини, кейинчалик, ўзимда назмхонлик қилиш эмас, балки бирон мухим ва юрагимда тугилиб қолган фикрни баён қилиш зарурати етилгач, тушундим...

Мен энди шеърларга ўз рухий тарихимнинг бир парчасини жойлаштира 
бошладим, бу парчанинг ўз тугуни, кульминацияси ва ечими бор эди. Энди ёзмоқ учун, Лев Толстой айтганидек, дастлаб газнинг учини учига улаб олишим керак эди. Шеърни бошлаб қўйиб, охирини топмагунимча, уни давом эттира олмас эдим. Эндиликда қаёққа қараб кетаётганлигимни билганимдан йўлнинг энг қисқасини излаб топиб олардим, натижада шеьрларим кўнгилдагидай бўла бошлади”(“Камалак”, 145-б).

Зулфия рус шоирларидан А.Пушкинни, Н.Некрасовни алохида бир мехру мухаббат билан севганини мақола ва сухбатларида тез-тез эсга олади. Улуғ шоирларнинг ўз рухиятига яқин кўплаб асарларини ўзбек тилида жаранглатиш бобида хам шоира кўп захматлар чеккан. Зулфиянинг бу шоирларга бунчалик эътиқод кўйишининг боиси улар ижодидаги инсонийлик, поклик, маънавий жасорат, бурч ва садоқат каби фазилатларнинг юксак пардаларда куйлангани бўлса, ажаб эмас: "Классик шоирларнинг кишига таъсир этадиган ажойиб кучи ва киши билмас сири бор, чоғи. Масалан, Сиз Пушкиннинг "Тунги туман ухлар Грузия тепалигида" мисрасини олинг. Оддий, жуда оддий сўзлар. Лекин, бу ерда, бу сўзларнинг замирида қанча шеърият ва теран маъно бор. Бу манзарани, табиатдаги кайфиятни ёлғиз худди шундай сўзлар билан, фақат шундай иборалар билангина ифода этиш мумкиндай гуё. Бу ерда гўё хамма нарса аниқ тўла айтилган, содда, чукур ва жонли.

Пушкин шеъриятининг кудрати, назаримда шундаки, Сиз уззингиз учун энг оғир дақиқаларда ўқисангиз хам, Сизни бутун бир бошқа дунёга олиб чиқади. Сизни гуё бахор эркалаб ўтади. Дилингизни рутубатлардан тозалайди. Бу Пушкин шеьриятининг хар бир дилни куйлашга чорловчи фусункор наъмаси, сўзларда парча-парча бўлиб яшаб қолган шоир юрагининг оташлари!

Улкан шоир Пушкин дунёга келган замон билан бизнинг ўртамизда юз йиллар ястаниб ётибди. Қанча шоирлар келибкетмади. Кимлар қолди, кимлар қолмади. Зеро, замон ғалвири шундай шаддод, адолатлики, ёлғиз хақиқатгина унинг хаётий синовларига тоб бериб қола олади. Пушкин ана шундай яққол хақиқат, Пушкин ижоди - замонлар ўтган сари заминда кенгроқ ёйилиб, тўлиб оқаётган хақиқат дарёси. Замондан замонга буюклиги билан тобора донг таратаётган ўлмас шоир - Пушкин!” (“Камалак”, 197б.)

Дархақиқат, Пушкин дахоси илгари сурган умумбашарий ғоялар асрлар оша кўплаб халқларнинг миллий шеъриятида акс-садосини бермокда. Унинг шеьрларида гавдаланган қахрамонларнинг эзгу ўйниятлари, самимий хис-туйғулари кўплаб шоирларни қўлга қалам олишга ундаши турган гап. Улуғ санъаткорларнинг дунёни идрок қилиш ва тасвирлаш усуллари шу қадар ёрқин бўладики, бошқалар хам беихтиёр уларга эргашиб, шу йўсинда шељр ёза бошлаганини билмай қоладилар. Бироқ асл санъаткорлар буюкларни такрорламайдилар, улардан таъсирланиб, янги санъат намунасини дунёга келтирадилар. Бунга Зулфиянинг “...йиллар ўтган сайин ўз-ўзингга талабчанлигинг ошиб боради. Тажрибанг қанча кўпайса, бировларнинг эски ё янги шеърлари билан қанча кўп танишсанг, бирон чинакам гап топиб айтишинг нақадар зарурлигини шунча яққол хис қиласан", деган сўзлари мисол бўла олади.

Адабиётшунос Улуғбек Хамдам замонавий адабиёт илмидаги "муаллиф ўлими”, “интертекстуаллик” тушунчалари хақидаги қарашларини баён қилар экан, тақлид, таъсир, атайинлик, ижодий таъсирланиш каби ходисаларнинг хар бирига алохида тўхталади. Айниқса, унинг “интертекстуаллик" тушунчасига берган изохи асосли бўлиб, ижодий таъсир масаласини бир қадар ойдинлаштиришга кўмаклашади: “...Инсон боласи дунёга келиши билан атрофга ўрганишга мойил кўзларию кулоқларини тикади. Унинг билими оламдан ва одамдан келади. Шаклланиши мобайнида сўз, гап, гап конструкциялари, матн... буларнинг барини у ташқаридан, жамиятдан, одамлардан уурганади. Ранглару товушларни хам худди шундай, тап-тайёр 
холда қабул қилади. Бошқача айтганда, саналганларнинг хаммаси - бир қолип. Инсон хар қандай фикрни ана шу қолиплару шакллар ёрдамида ифода қилади. Шунинг ўзиёқ инсон томонидан яратилган хар қандай ижод намунаси мутлақ аслият эмаслигига далил. Бинобарин, ёзувчи асари хақиқатан хам интерматн, яъни матнлар ичида матндир" $[4,128]$.

Энди реминисценция ва интертекстуаллик терминлари англатадиган маънолар мағзини чақиб кўришга харакат қиламиз. Бадиий матнда ўзидан аввалги адабий маълумотларга; алохида бадиий асар ёки асарлар гурухига хавола қилиш, илгариги асарларни эслатиш реминисценция термини билан изохланади. Бошқача айтганда, реминисценция - адабиётдаги адабиётлар образларидир. Унинг энг кўп тарқалган тури аниқ ёки ноаниқ, “қўштирноққа олинган” ёки тагмаъно орқали англашиладиган яширин парчадир. Реминисценциялар муаллиф томонидан асарга онгли тарзда ва бирор мақсадни кўзлаб киритилиши ёки унинг иродасидан ташқари, беихтиёр кириб қолиши (хотирланиши) хам мумкин.

Парча холидаги реминисценциялар муаллифники бўлмаган нутқнинг алохида кўринишларидан хисобланади. Улар ижодкорнинг ўз салафлари қарашларини қабул қилиши ва маъқуллашини ёки аксинча, илгари яратилган матнга ўхшатма қилиш асносида бахслашиш ниятида эканлигини билдиради: “...парча келтиришлар қанчалик хилма-хил бўлмасин, хар хил ва аксар бир-бирига ўхшамаган “овозлар” шундай контекстда тажассум топадики, ундаги ўзгалар сўзи орқали муаллиф фикри (унинг ўзга фикрни маъкуллаши ёки рад этиши) англашилади" $[1,71]$. Бунга шоиранинг "Пушкинга" шеърида Навоийдан келтирилган парчани мисол келтириш мумкин:

Навоий демишки:

"Шеьр - дил хамрохи".

Бугун юлдуздан кўп Сиз хамрох диллар.

Қани эшитсангиз, қай жаранг, оханг
Ўқир ўз тилида Сизни не эллар! (“Тонг билан шом аро”, 76-б.)

Айни пайтда, реминисценциялар сохаси ўзгалар асаридан парча-кўчирмалар келтиришдан кўра анча кенгроқ. Зулфиянинг баъзи шеърларида устоз ёки замондош ижодкорларнинг асарлари эслаб ўтилади, бу асарларни яратган шоирлар дахосига эхтиром - муносабат сезилиб туради. Мисол учун, Ойбек хақидаги "Қуёшли қалам" достонида улуғ шоир ёзган асарларга хавола қилинади, реминисценциянинг ўзгача бир кўриниши бўй кўрсатади:

Қизча - Хурилиқо сехрлангандай.

Кўзин узмай турар шоир юзидан,

"Ким эди бу яқин таниш, бузруквор?”

Фикрин қийнаганин уқиб кўзидан,

- Бу Ойбек домла-ку! - дейман сервиқор.

Кўзи офтоб чўккан чукур чашмадай

Тиниқ учқун билан ёниб кетади.

Дўлти лабда кулгу соф карашмадай

Энтикиб шодлигин баён этади:

“Кутлуғ қон”,

"Навоий...

“Қизлар” достони...

Хаммасини ёзган домлами чиндан?

Нигох-ла эркалаб Хурилиқони,

Адиб ўй суради ё ёзар зимдан (“Тонг билан шом аро”, 156-б.).

Шеъриятда бошқа санъатларнинг реал хаётда мавжуд ёки тўқима орқали ўйланган намуналари хам адабий реминисценциялар кўринишида учраши мумкин. Бунга шоиранинг рассом Чингиз Ахмаровга атаб ёзган шеърини мисол келтириш мумкин. Зулфия рассом мўйқаламининг кучи билан қайта тирилган аждодларимиз сиймоси олдида хайратдан лол қотади, суратда тасвирланган образлар парча-парча холида шеьрга кўчади, томошабин-китобхон рассомлик санъатининг нозик сирлари билан таниша бошлайди.

Шоирлар ижодида, жумладан, йирик шоирларда хам, турли-туман манбалардан олинган кўплаб реминисцециялар учрайди. Зулфия асарлари - унинг лирикаси, достонлари миллий ва хорижий 
адабиётларга хар турли хаволалар билан лиқ тўла. Уларда Навоий, Бобур, Зебунисо, Байрон, Шекспир, Пушкин, Некрасов, Цветаева, Миртемир, Х.Олимжон, Ойбек ва бошқа кўплаб санъаткорларнинг ёрқин сиймолари қад кўтарган. Турфа хил реминисценцияларда шоиранинг ўзидан аввалги ва замондош ижодкорлар санъатини юксак эхтиром билан қабул қилиши хам, улар билан ижодий бахслашишлари хам, айрим стереотипларни хушламаслиги хам билиниб туради.

Адабий таъсир, ўзаро ижодий хамкорлик хақида гап кетар экан, аввало Зулфиянинг хассос шоира бўлиб шаклланишида алохида из қолдирган Хамид Олимжонни эслаш жоиздир. Зулфия шоир билан бирга кечган бахтиёр йилларда хар қандай истеьдод доимий мехнат туфайли чархланиб бориши, хақиқий санъаткор буюк мехнат интизомига эга бўлиши лозимлигини кўрди. Хамид Олимжон хар қандай шароитда хам эрта билан соат 6 дан 11 га кадар уйда ижод билан шуғулланар, сўнг хали сиёхи қуримаган асарини овоз чиқариб ўқир ва унинг қандай жаранглашини текшириб кўрар эди.

Зулфия ўзининг хар бир шеърини унинг назаридан ўтказар, аммо Хамид Олимжон бу шеърларга қалам урмас, балки улардаги кучли ва кучсиз сатрларини кўрсатар, тушунтирар эди. Зулфия Хамид Олимжон билан бўлган шундай сухбатлардан кейин шеър ёзган, шеърлари босилиб чиққан хар қандай киши хам шоир бўла олмаслигини, шоир бўлиш учун эса дунёни ўзгача кўриш ва идрок этиш зарурлигини тушунди.

Улкан шоир, нодир инсоний фазилатлар сохиби Хамид Олимжон Зулфияга, хамма нарсада ўрнак бўлди. Зулфия ундан фикрлаш, мехнат қилиш ва шеьр ёзишни хам, дўстларга мехрибон, душманга эса шафқатсиз бўлишни хам ўрганди, унинг ижод мактабида таълим олди. Хамид Олимжон шу маънода Зулфия қалбига уйғун хамрох ва сезгир маслахатчи бўлди. Қалбида шеърият булоғи кўз очаётган ёш шоира Хамид
Олимжондан шеърни қандай ёзиш сирларини қунт билан ўрганди.

"Мен ўша пайтларда: "Столга ўтирди дегунча ёзаверади. Қайдан бу куч, илхом?” деб таажжубланардим. Энди билсам, жахон, рус ва ўзбек мумтоз, замонавий адабиётини ўқиш, ўқибгина қолмай, уларни тахлил қилиш, фикрларини ён дафтарига ёзиб кўйиш, халқ оғзаки ижоди билан астойдил шуғулланиш - бу машғулотларнинг бари шоир ижоди учун доимий озиқ бўлиб турган экан. Хамид Олимжон шунча ишлар орасида менга хам астойдил ёрдам берар эди. Ёшман, баъзан менга сонсиз китоблар, қоғозлар ичида кўмилиб ўтириш ёқимли туюлмасди. Бундай пайтларда у мени илхомлантириш йўлларини топарди. Эсимда, бир гал Самарқанд сафаридан ўзи билан Раъно Узоқованинг шеьрларини олиб келди. Таъсирчан жойларини ўша кечадаёқ ўқиб берди. Сўнг: "Кўряпсизми, аёлларимиз қандай ёза олади? Фақат жасорат, ирода керак, - деди-да, секингина қўшиб қўйди. - Биласизми, сиз яхшироқ ёза оласиз! Бу сухбат менга катта туртки бўлди".

Зулфия Хамид Олимжон таъсирида ўзбек, жахон ва рус мумтоз шоирларининг шеърларини мутолаа қилди. Уни, хусусан, Пушкин, Тютчев, Фетнинг мусиқий равон мисралари, айниқса, ром этди. У, мархум адабиётшунос Адхам Акбаровнинг гувохлик беришича, Афанасий Фетнинг "Салом билан келдим сенинг ёнингга..." шеьрини ўқиш билан эрта тонгда севимли ёрини уйғотадиган бўлди. Ўша кунларда Зулфия қуёшнинг илк нурлари билан турибоқ Фетнинг ушбу сехрли мисраларини рус тилида баланд овоз билан ўқир ва унинг кўнғироқдек янгроқ ва ёқимли овози дилнавоз тонг отганлигини англатар эди.

Я пришел к тебе с приветом,

Рассказать, что солнце встало,

Что оно горячим светом

По листам затрепетало.

Рассказать, что с той же страстью,

Как вчера я пришел снова.

Что душа все так же счастью

И тебе служить готова... 
Бу мисралар гарчанд Фет қаламига мансуб эса-да, улар Зулфия қалбининг ўша кезлардаги замзамалари, жилвалари, тебранишларини ифода этар ва унинг қалб овозидек янграр эди. Эътибор беринг-а:

Ёнингга мен келдим салом-ла,

Айтиш учун офтоб кулганин,

Мехр тўла илиқ нури-ла

Баргчаларга зардек қўнганин.

Кечагидек айтгани келдим,

Хокимлигин дилда эхтирос.

Бутун қалбим бахт билан сенга

Хизмат қилай дегани хам рост... (Таржима бизники - Г.У.)

Барча бахтиёр кишилар бирбирларига ўхшайдилар. Бахтиёр инсон дилнавоз ошиқ ёки маъшуқага ўз қалбининг биллур туйғуларини нисор этади. Зулфия хам, Хамид Олимжон хам ўша чароғон йилларда қалб кўрини, мехрмухаббат тафтини бир-бирларидан сира фориғ тутмадилар. Бу оила икки шоирнинг ўзаро хурмат ва мухаббатга асосланган эркин иттифоқи эди.

Шу даврда Зулфия ижоди бахор чоғларидаги чўққилардан эндигина пайдо бўлаётган кичик бир жилға эди. Кунлар, ойлар ва йиллар ўтиб бу жилға улкан дарёга айланди, ўзанларидан тошиб, мавжланиб оқди.

1. Левин Ю.И., Сегал Д.М., Тименчик Р.Д., Топоров В.Н., Цивьян Т.В. Русская семантическая поэтика как потенциальная культурная парадигма // Russian literature. 1974. № 7/8. - P. 71.

2. Назаров Б. Адабий таъсир ва типологик яқинликни ўрганишнинг айрим методологик масалаларига доир. // Ўзбек адабиёти қиёсий адабиётшунослик аспектида: таъсир ва типология (республика илмий-назарий конференцияси материаллари). - Тошкент: "Muharrir nashriyoti", 2013. - Б. 6.

3. Зулфия. Асарлар. Камалак. 3-жилд. - Т.: Fафур Ғулом номидаги Адабиёт ва санъат нашриёти, 1986.

4. Хамдам У. “Муаллиф ўлими”га сиз хам овоз берасизми (ёки асл ижод соғинчи)? // Шарқ юлдузи, № 1, 2014. - Б. 128.

Умурова Г. Результаты художественного воздействия на творчетсов Зульфии. В данной статье речь идёт о художественном воздействие и его положительных результатов. Значение и роль художественного воздействия в творчестве Зульфии освещяается на анализах её стихотворений.

Umurova $G$. The results of literary influence on Zulfiya's poetry. This article discusses the literary influence and its positive results. The role of literary influence is proved on the material of Zulfiya's works and by analyzing poetess's poems. 